\title{
Integrating XBRL Technology Into Accounting Curriculum: A Survey of Accounting Lecturers in Medan City
}

\author{
Khairunnisa Harahap ${ }^{1 *}$, Tapi Rumondang ${ }^{1}$, Pasca Dwi Putra ${ }^{2}$, Jumiadi Abdi \\ Winata $^{1}$
}

${ }^{I}$ Department of Accounting, Faculty of Economics, Universitas Negeri Medan, Indonesia

${ }^{2}$ Department of Business Education, Faculty of Economics, Universitas Negeri Medan, Indonesia

*Corresponding author. Email: nisaharahap77@gmail.com

\begin{abstract}
The purpose of this study is proposing how to apply an ideal XBRL-related curriculum and depth in course. Extensible Business Reporting Language (XBRL) is a significant new information technology for the electronic communication of business and financial data. XBRL has been a widely accepted standard and implemented in Indonesia beginning for sharia banking. All listed banking institution in Indonesian Stock Exchange publish their financial statement in XBRL format voluntary. Several accounting programs overseas has applied XBRL course into their curriculum. Many studies have shown that XBRL education plays important role in XBRL adoption. In order to implement XBRL successfully in Indonesia, therefore it is important to adopt XBRL related topics to the accounting curriculum in Indonesian educational institutions. The study results $75 \%$ of respondents has some familiarity with XBRL and the rest of it (25\% of respondents) is completely unfamiliar. While $62.5 \%$ of respondents describe their students are enough familiar with XBRL and $37.5 \%$ is completely unfamiliar with. A quarter of respondents think of integrating XBRL into curriculum is by not covering XBRL at all, $25 \%$ of respondents think of including in an accounting information system course, another $25 \%$ suggest to offer a separate entire course, and the others suggest to include in computer class. It is showed $37 \%$ of total respondents are strongly agree that the current accounting curriculum does not provide sufficient coverage of XBRL. The topics of XBRL which are concept of markups and tags; elements, attributes and namespaces in XML; document type definitions; XML schema; XSL (extensible style sheets); XBRL components; preparing and validating XBRL reports; XML/SBRL software; strategic uses of XBRL should be covered 75\% into accounting curriculum. There were some obstacles that made all the recommended course-designs could not be adopted to all related subjects in the current curriculum at once (big-bang approach). The recommended course designs were adopted only for selected subjects per academic year (phased approach). However, in the subsequent academic years, the XBRL related course designs in previous academic years have to be evaluated or even enhanced as the obstacles will be reduced gradually.
\end{abstract}

\section{Keywords: XBRL, Accounting Curriculum, Integrating XBRL and Accounting Information System}

\section{INTRODUCTION}

Technology utilization in corporate financial statements is considered very important. There are two main problems that are still faced by companies in the presentation of their financial statements, namely in the process of data management and information distribution. Data integration and system compatibility are problems that are often experienced in processing accounting data. Whereas in terms of distribution, diverse user needs, especially those relating to the format of presentation of financial statements, require companies to present financial statements in more than one format.

The development of a new reporting system technology, XBRL, can fundamentally change the way business is about providing information to investors, markets and regulators, and how each stakeholder group makes more informed decisions. [2] states that research in America and Australia shows that XBRL learning plays an important role in the adoption of XBRL. Requesting to implement XBRL successfully in Indonesia, it is necessary to link the topic of adopting XBRL into the Accounting curriculum in Indonesian educational institutions. This is in accordance with the efforts of the Indonesian Compartment of Accountants Association to include XBRL material into the syllabus of the Accounting Information System Course. A research by [2] conducted at the Banjarmasin Polytechnic Accounting Study Program, found that XBRL could not be applied to 
all accounting subjects at this time. This study recommends that XBRL material can be applied to several subjects that are directly related to XBRL technology, such as Management Information Systems subjects, Accounting and Computer Accounting Information Systems. Although actually $\mathrm{XBRL}$ is also considered to have a significant impact on accounting and auditing. XBRL is a concept of uniformity in the delivery of quantitative financial statements, so as to provide convenience in analyzing the regulator, to analysts.

The Indonesia Stock Exchange launched an issuer's reporting system using extensible business reporting language (XBRL) on June 22, 2015 [3]. BEI's President Director [4], Warsito said this system had been developed since 2013 which was one of the important points for Indonesian issuers and investors. The Chief Executive of the Capital Market Supervisor of the Financial Services Authority (OJK), Nurhaida said the capital market industry needs integrated, quality and transparent reports. Because transparent data is needed by all parties. OJK and IDX consider integrated data will help the supervision process. From the investor side, it will also be very helpful because all this time the data format used by the issuer is still diverse. If you want to do an analysis of the financial statements, it will take even longer.

Gradually, the IDX will require issuers to submit XBRL Financial reports. After the training, starting in August 2015, all issuers will be required to submit an XBRL-based financial report with a deadline of 1 month longer than the non-XBRL financial statement obligation. The adoption of XBRL starts in the Islamic banking sector.

$\mathrm{XBRL}$ is the latest information technology for electronic business communication and financial data. Just as IFRS convergence does not only require accountants to update their knowledge, but also educators to always improve their competence in understanding and applying IFRS. In order to optimize the implementation of XBRL in Indonesia, it is therefore important to adopt XBRL into the Accounting curriculum in Universities in Indonesia. The implementation of XBRL in a country requires collaboration between institutions. This is because XBRL not only requires technology (IT) support, but more than that is the standardization readiness (taxonomy) and regulations that govern its implementation. The development and implementation of XBRL must also coordinate with academics in universities in preparing skilled workers who can understand and apply XBRL technology in the world of work.

To be able to produce accounting graduates who have competencies related to information system technology, universities need to integrate XBRL into the curriculum. This study continues the research conducted by Rahwani [2] on how to integrate XBRL into the accounting curriculum at Banjarmasin State Polytechnic by using a model that is the brainchild. The findings of this research are that there are obstacles that make the curriculum design offered cannot be adopted for all courses due to the following reasons:

1. Not all lecturers understand XBRL well.

2. Very little research related to the implementation of XBRL in Indonesia.

3. Very few modules related to XBRL in Indonesia.

4. There is no procedure manual regarding the XBRL application in Indonesia.

So in his research [2] stated that the adoption of XBRL into the accounting curriculum could only be inserted in three subjects namely management information systems, accounting information systems, and computer accounting. The deeper the accounting concepts learned from a subject, the more in the XBRL topic that must be taught. This study wants to find out whether XBRL material has been included in the accounting curriculum or not, if it has been included in the curriculum, where is the scope of the topic and how to prepare majors, perceptions and understanding of accounting lecturers on XBRL technology content, especially in Management Information Systems courses Accounting and Computer Information Systems Accounting at Universities in the city of Medan through surveys. Given that accounting students must be responsive to all future professional developments related to the application of XBRL, the authors feel this topic is important to be examined.

\section{LITERATURE REVIEW}

\subsection{The definition of $X B R L$}

XBRL arises because of the integration between information technology and business needs. Currently XBRL has become a standard format in the delivery and exchange of financial and business information. Every data or element in the financial statements will have a special identity, this identity will make the data more useful. Each user can also customize information and access financial information according to the format they want more accurately. XBRL comes from a technological revolution in progress that will affect how financial statements are prepared. XBRL allows financial statements to be communicated and processed automatically by computer software, providing great benefits in speed and efficiency, cost savings and improving accuracy for all who use financial statements. XBRL is able to accommodate the 
semantic requirements of financial reporting which involve the double link between one element and another element in multiple relationships, XBRL also has extensibility features that are far better than XML [5].

[6] explained, at first XBRL was indeed developed as a technology for financial reporting or business reporting. However, the application of XBRL continues to be expanded so that it also includes qualitative non-financial information. Examples of the application of XBRL for nonfinancial reporting are the use of XBRL in the submission of corporate social responsibility reports, the IIRC initiative (International Integrated Reporting Council), and the GRI (Global Reporting Initiative) in the Asian region.The function owned by XBRL is not only enjoyed by companies that present financial statements but also by those who utilize financial statements. XBRL creates a better reporting model compared to paper and electronic based financial reports in HTML, PDF, DOC and XLS formats. XBRL facilitates the creation of a more concise information distribution channel. Therefore, XBRL can be used to prepare financial statements in a format that can be operated in a variety of applications, meaning it reduces the need to prepare the need to prepare financial statements in different formats.

\subsection{Benefits of XBRL}

According to [7], the benefits of XBRL can make it easier to apply financial analysis techniques, such as ratio analysis to compare companies or the performance of the same company in different periods in a much easier process than with financial statements (non interactive) traditionally produced. Whereas according to BAPEPAM-LK [8], in general, the benefits of XBRL are: Increasing the usefulness of electronic reporting systems because it implements: (a) Format that has been standardized, resulting in information and data that is 'comparable' and easy to analyze, (b) Validation automatically, so as to minimize input errors.

1. Facilitate the publication of reports (including financial statements) because XBRL can be reprocessed to the desired format: PDF, HTML, Excel, TXT, etc.

2. Improve access to financial information, especially for international investors, because XBRL applies an information identification standard. Foreign investors may make their analysis independently and make comparisons using their own language.

3. Accelerate business decision making for investors.
Some potential practical benefits of adopting XBRL are also conveyed [9] which include:

1. Increased exchanges within and between organizations.

2. Reduce the time needed to do business reporting tasks and the underlying process.

3. Improved environmental control, reduces data manipulation (both in the sense of innocence but not effective and in an eviler sense).

4. Facilitating the move to paperless business reporting.

5. Helping organizations adjust to the expanding industry-acceptance method.

6. Supported by major software vendors that allow new functionality and efficiency.

7. Improved comparison and analysis of information reporting of several business companies.

\subsection{Accounting and XBRL Information Technology}

Technology Exceptional technological developments also have an impact on changes in modern accounting. XBRL is certainly important in the development of IT, XBRL is also valuable because the accounting profession began the development of XBRL. The XBRL development process provides a good overview of how accountants can be actively involved in the development of ongoing IT. The existence of XBRL which can be used to prepare financial statements in a format that can be operated in a variety of applications means reducing the need to prepare the need to prepare financial statements in different formats. Therefore, there will be time, cost and certain data errors on various documents. In summary, XBRL can accelerate, reduce business and increase reliability in accounting and auditing tasks, in accordance with the results of research conducted by [5] that XBRL technology is Efficient, where the efficiency of $22.42 \%$ compared to nonXBRL technology.

The Role of Information Technology in accounting is becoming increasingly important because rapid advances in Information Technology are very influential on the development and application of accounting science, especially in the subject of Management Information Systems, Accounting Information Systems and Computer Accounting. The role of an accountant can include three fields: designer, user and examiner (auditor) so Information Technology will play a major role in the success of the accountant's work.

For accounting students in Indonesia, it should be realized that the existing curriculum does not support 
the creation of an accountant who is also reliable in the field of IT. Reliable in the sense of understanding and being able to use IT in supporting the role of an accountant. Of course, knowledge of IT is not everything in the context of accounting information systems science. Other understanding is needed such as database, good reporting, control, business operation, transaction processing, decision making management development and system use, communication, and understanding of accounting and audit principles. For this reason, accounting students must be responsive to all future professional developments related to the development of information technology.

The results of research conducted by [1] represent responses that lead to the urgency and scope of XBRL topics in the accounting curriculum. The topic's urgency is closely related to the scope of the topic itself and around $85 \%$ (44 of 52 respondents) believe that XBRL is an important topic. This study replicates the research and [2] regarding the integration of XBRL material into the accounting curriculum.

\section{RESEARCH METHODS}

This research is a descriptive research by analyzing individual answers from the questions in the questionnaire. This study uses an independent variable, namely the integration of XBRL technology into the accounting curriculum [10]. Research data is primary data collected using a questionnaire consisting of three parts through closed questions. The use of questionnaires refers to the questionnaire used by [1] as well as the operational measurement variables contained in the questionnaire.

The sample of the study was the educator accountants in various universities in the city of Medan, both state and private universities and vocational education. This sample was taken by purposive sampling technique with the criteria of only distributing questionnaires to lecturers teaching courses in Management Information Systems, Accounting and Computer Accounting Information Systems, in accordance with recommendations from Rahwani's research [2]. The distribution of questionnaires was carried out via email and Social Media (WhatsApp) to respondents who were accessed by researchers. The analytical method is quantitative descriptive. Respondents' answers to closed questions in the questionnaire will be calculated and their mean scores (mean) for later described as answers to the formulation of the research problem.

\section{RESEARCH RESULTS DISCUSSION}

\subsection{Questionnaire Distribution and Returns}

This study uses questionnaires distributed to educator accountants for data collection. The research sample is an accounting lecturer who teaches courses in Management Information Systems, Accounting and Computer Accounting Information Systems in the Accounting Department at the Faculty of Economics at State and Private Universities in Medan City. Of the 30 questionnaires distributed to the lecturers, which were returned after 20 questionnaires were filled. Because the lecturers who teach courses in Management Information Systems, accounting and Computer Information Systems accounting are not so many. Questionnaires returned were from lecturers at Medan State University, Muhammadiyah University, Panca Budi University and Medan Polytechnic.

\subsection{Results and Discussion Part One}

The first part of the question submitted to the respondent is the respondent's demographic data.

Table 1. Demographic Information on Respondents

\begin{tabular}{|c|c|c|c|c|c|}
\hline No & Questions & \multicolumn{3}{|c|}{ Answer } & Total \\
\hline \multirow[t]{2}{*}{1} & \multirow[t]{2}{*}{ Choose your academic level } & Professor & Doctoral & Master's & \multirow[t]{2}{*}{$100 \%$} \\
\hline & & & $11.1 \%$ & $88.9 \%$ & \\
\hline \multirow[t]{2}{*}{2} & \multirow[t]{2}{*}{ What is the main course you teach? } & $\begin{array}{c}\text { Accounting } \\
\text { Information } \\
\text { Systems } \\
\end{array}$ & $\begin{array}{l}\text { Computer } \\
\text { Accounting }\end{array}$ & $\begin{array}{c}\text { Management } \\
\text { Information } \\
\text { Systems }\end{array}$ & \multirow[t]{2}{*}{$100 \%$} \\
\hline & & $55.6 \%$ & $22.2 \%$ & $22.2 \%$ & \\
\hline \multirow[t]{2}{*}{3} & \multirow{2}{*}{$\begin{array}{l}\text { Is your economics faculty } \\
\text { accredited? }\end{array}$} & $\mathbf{A}$ & B & $\mathbf{C}$ & \multirow[t]{2}{*}{$100 \%$} \\
\hline & & $66.7 \%$ & $33.3 \%$ & & \\
\hline \multirow[t]{2}{*}{4} & \multirow{2}{*}{$\begin{array}{l}\text { What is your accounting study } \\
\text { program accreditation? }\end{array}$} & $\mathbf{A}$ & B & $\mathbf{C}$ & \multirow[t]{2}{*}{$100 \%$} \\
\hline & & $77.8 \%$ & $22.2 \%$ & & \\
\hline \multirow[t]{2}{*}{5} & \multirow{2}{*}{$\begin{array}{l}\text { Are you serving a professional } \\
\text { accountant role? }\end{array}$} & Yes & No & & \multirow[t]{2}{*}{$100 \%$} \\
\hline & & $77.8 \%$ & $22.2 \%$ & & \\
\hline
\end{tabular}

From the table above, it can be seen that the most academic level of respondents is the Masters of $88.9 \%$, then followed by respondents who have an academic level of Doctor. This data shows that accounting lecturers who teach SIA, SIM and accounting computer courses have an academic level 
of Masters. From the results of this survey, it is also known that the biggest respondents are lecturers who teach Accounting Information Systems courses, these results are as expected by researchers.

In the next question sequence shows that from the survey results as much as $66.7 \%$ of the accreditation level of the Economic faculty in the survey has an A rating and the rest has a B rating. The results of this survey also indicate that the accounting study program accreditation in the survey has an A rating of $77.8 \%$ and the rest are ranked B. Respondents surveyed in this study are accountants as much as $77.8 \%$ and the rest are accounting educators.

\subsection{Results and Discussion Part Two}

Questions second part posed to the respondents is as follows:

1. Describe the level of your understanding on XML / XBRL

2. Describe the level of understanding of your students on XML / XBRL

Table 2. Description Answer Respondents Part Two: Knowledge of Respondents Regarding XBRL

\begin{tabular}{|c|l|c|c|c|c|}
\hline No & \multicolumn{1}{|c|}{ Question } & \multicolumn{2}{|c|}{ Answer } & Total \\
\hline 6 & $\begin{array}{l}\text { Describe your level of understanding in XML / } \\
\text { XBRL }\end{array}$ & $\begin{array}{c}\text { Not Understand } \\
\text { Completely }\end{array}$ & $\begin{array}{c}\text { Not So } \\
\text { Understand }\end{array}$ & $\begin{array}{l}\text { Understand } \\
\text { Completely }\end{array}$ & $100 \%$ \\
\cline { 3 - 5 } & \multicolumn{2}{|c|}{$22.2 \%$} & $77.8 \%$ & \\
\hline 7 & $\begin{array}{l}\text { Describe your students' level of understanding on } \\
\text { XML / XBRL }\end{array}$ & $\begin{array}{c}\text { Not Understand } \\
\text { Completely }\end{array}$ & $\begin{array}{c}\text { Not So } \\
\text { Understand }\end{array}$ & $\begin{array}{c}\text { Understand } \\
\text { Completely }\end{array}$ & $100 \%$ \\
\cline { 3 - 4 } & & $33.3 \%$ & $66.7 \%$ & & \\
\hline
\end{tabular}

Of the respondent's answer description in table two shows the level of respondents' knowledge of XBRL Material, more than half of the respondents said that they only had enough knowledge about XBRL material as much as $77.8 \%$ said that they did not know anything at all. The next question describes the level of students' understanding of the XBRL material which states that $66.7 \%$ said they were quite understanding while $33.3 \%$ said they did not understand at all. The results of this survey indicate that this XBRL material is in the form of new things so that no accountant lecturer said that he was very understanding.

From the results of this survey shows that in fact the respondents have shown a positive response to technological developments related to financial reporting systems that use XBRL technology. The results of this survey also show that accounting lecturers have also started introducing XBRL to students even though it is still an introduction. This result is in accordance with the recommendations of Rahwani's research [2] that at the undergraduate level, the XBRL material taught is only in the form of an introduction that is not so deep. But the results of this survey also show that technological developments related to the financial reporting system have not been socialized in universities evenly, because there are still many accounting lecturers who do not know and do not understand XBRL technology. The answers to these questions indicate that some universities are slowing down in responding to the demands of higher education stakeholders (companies) who need accountants who have integrative abilities, including the ability to master technology.

\subsection{Results and Discussion Part Three}

The third part of the question submitted to the respondents is about how to integrate XBRL material into the accounting curriculum, the material that is important to be included in the curriculum and what method is most appropriate in presenting XBRL material into the accounting curriculum.

Table 3. Descriptions of Respondents' Answers Part Three: Integrate XBRL into the Accounting Curriculum

\begin{tabular}{|c|c|c|c|c|c|c|}
\hline No & Question & \multicolumn{4}{|c|}{ Answer } & Total \\
\hline \multirow[t]{2}{*}{8} & $\begin{array}{l}\text { How do you integrate XBRL } \\
\text { topics into the curriculum? }\end{array}$ & $\begin{array}{c}\text { Does not } \\
\text { include XML } \\
\text { / XBRL } \\
\text { completely }\end{array}$ & $\begin{array}{l}\text { covers the } \\
\text { topic of } \\
\text { XBRL in } \\
\text { the course }\end{array}$ & $\begin{array}{l}\text { Presenting the } \\
\text { course itself }\end{array}$ & $\begin{array}{l}\text { covers topics } \\
\text { XBRL in } \\
\text { computer class } \\
\text { accounting }\end{array}$ & \multirow[t]{2}{*}{$100 \%$} \\
\hline & & $22.2 \%$ & $33.3 \%$ & $22.2 \%$ & $22.2 \%$ & \\
\hline \multirow[t]{2}{*}{9} & \multirow{2}{*}{$\begin{array}{l}\text { If you do not present XBRL in } \\
\text { the curriculum, when the } \\
\text { institution you plan to enter } \\
\text { topic XBRL? Ignore if your }\end{array}$} & in a year & $\begin{array}{l}\text { in two } \\
\text { years }\end{array}$ & $\begin{array}{c}\text { in five years, } \\
\text { do }\end{array}$ & not plan & \multirow[t]{2}{*}{$100 \%$} \\
\hline & & $55.6 \%$ & $22.2 \%$ & $11.1 \%$ & $11.1 \%$ & \\
\hline
\end{tabular}


institution has entered the

topic

Determine the level of importance of entering the following topics in the accounting information system course or the auditing course module marked with number $1=$ not important and $5=$ very important.

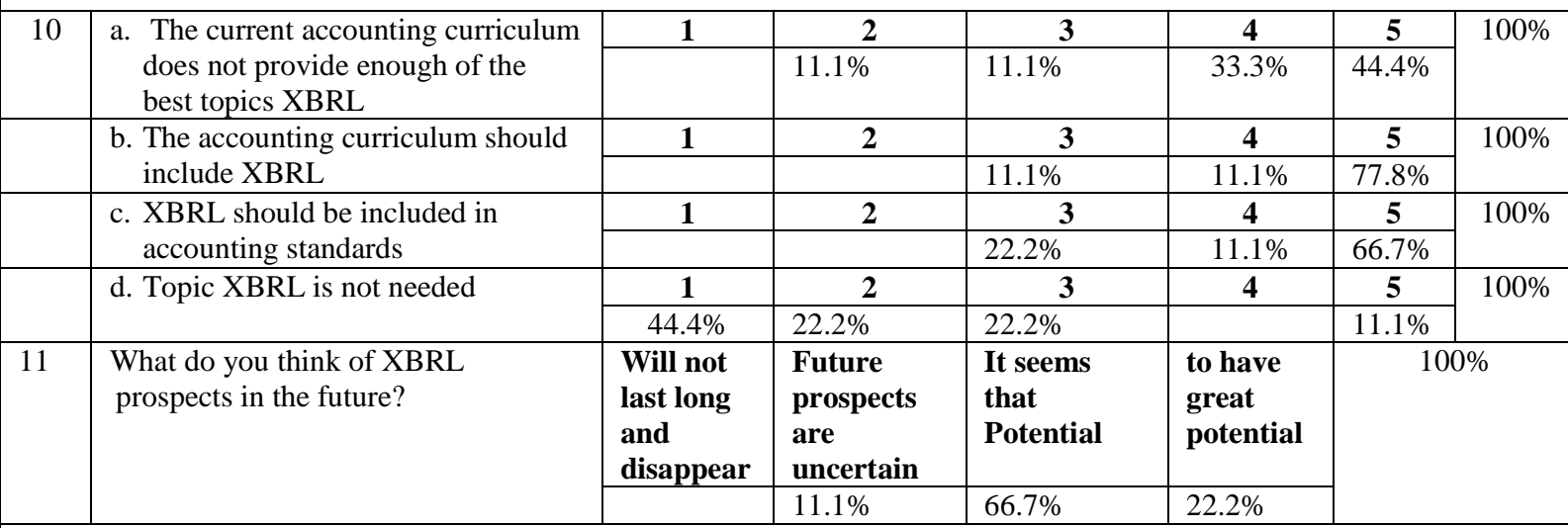

Determine the obstacles faced when integrating XBRL topics into the curriculum Accounting $(1=$ there are no obstacles and $5=$ very heavy $)$

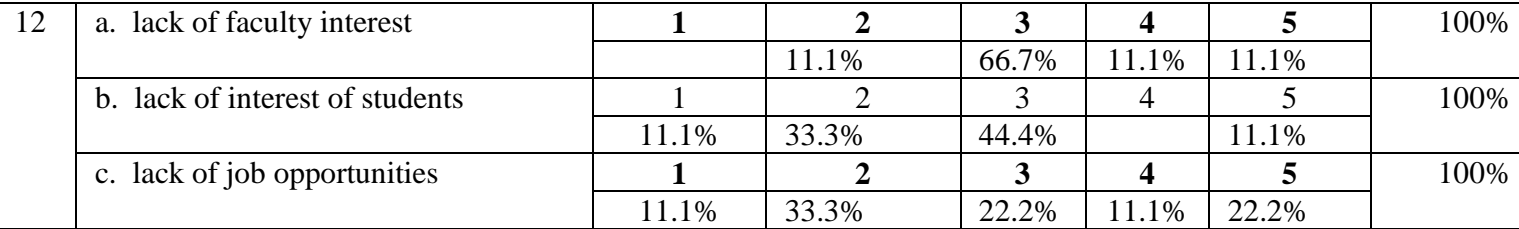

The following is a list of materials in XBRL. Determine the importance of each material $(1=$ not important and $5=$ very important $)$

\begin{tabular}{|c|c|c|c|c|c|c|}
\hline \multirow[t]{2}{*}{ a. The concept of markup and price } & 1 & 2 & 3 & 4 & 5 & \multirow{2}{*}{$\begin{array}{c}100 \\
\%\end{array}$} \\
\hline & & & $44.4 \%$ & $33.3 \%$ & $22.2 \%$ & \\
\hline \multirow{2}{*}{$\begin{array}{l}\text { b. Elements, attributes, and namespace in } \\
\text { XML }\end{array}$} & 1 & 2 & 3 & 4 & 5 & \multirow{2}{*}{$\begin{array}{c}100 \\
\%\end{array}$} \\
\hline & & & $44.4 \%$ & $33.3 \%$ & $22.2 \%$ & \\
\hline \multirow[t]{2}{*}{ c. Document type definitions } & 1 & 2 & 3 & 4 & 5 & \multirow{2}{*}{$\begin{array}{c}100 \\
\%\end{array}$} \\
\hline & & & $22.2 \%$ & $44.4 \%$ & $33.3 \%$ & \\
\hline \multirow[t]{2}{*}{ d.XML Scheme } & 1 & 2 & 3 & 4 & 5 & \multirow{2}{*}{$\begin{array}{c}100 \\
\%\end{array}$} \\
\hline & & & $22.2 \%$ & $44.4 \%$ & $33.3 \%$ & \\
\hline \multirow[t]{2}{*}{ e.XSL (eXtensible style sheets) } & 1 & 2 & 3 & 4 & 5 & \multirow{2}{*}{$\begin{array}{c}100 \\
\%\end{array}$} \\
\hline & & & $33.3 \%$ & $33.3 \%$ & $33.3 \%$ & \\
\hline \multirow[t]{2}{*}{ f. Component XBRL } & 1 & 2 & 3 & 4 & 5 & \multirow{2}{*}{$\begin{array}{c}100 \\
\%\end{array}$} \\
\hline & & & $22.2 \%$ & $22.2 \%$ & $55.6 \%$ & \\
\hline \multirow[t]{2}{*}{ g. XBRLreport preparation and validation } & 1 & 2 & 3 & 4 & 5 & \multirow{2}{*}{$\begin{array}{c}100 \\
\% \\
\end{array}$} \\
\hline & & & $44.4 \%$ & $33.3 \%$ & $22.2 \%$ & \\
\hline \multirow[t]{2}{*}{ h. XSL / XBRL Software } & 1 & 2 & 3 & 4 & 5 & \multirow{2}{*}{$\begin{array}{c}100 \\
\%\end{array}$} \\
\hline & & & $33.3 \%$ & $22.2 \%$ & $44.4 \%$ & \\
\hline \multirow[t]{2}{*}{ i. XBRL strategic use } & 1 & 2 & 3 & 4 & 5 & \multirow{2}{*}{$\begin{array}{c}100 \\
\%\end{array}$} \\
\hline & & & $33.3 \%$ & $22.2 \%$ & $44.4 \%$ & \\
\hline
\end{tabular}

The following is a list of top-topics in XBRL. Determine the level of depth of coverage of each of these topics in your curriculum

$(1=$ not included, $5=$ very deep $)$

\begin{tabular}{|l|l|c|c|c|c|c|c|}
\hline 14 & a. The concept of markup and prices & $\mathbf{1}$ & $\mathbf{2}$ & $\mathbf{3}$ & $\mathbf{4}$ & $\mathbf{5}$ & 100 \\
& & $11.1 \%$ & & $44.4 \%$ & $11.1 \%$ & $33.3 \%$ & $\%$ \\
\hline & \multirow{2}{*}{ b. Lack of faculty interest } & $\mathbf{1}$ & $\mathbf{2}$ & $\mathbf{3}$ & $\mathbf{4}$ & $\mathbf{5}$ & 100 \\
& & & $11.1 \%$ & $66.7 \%$ & $11.1 \%$ & $11.1 \%$ & $\%$ \\
\hline & c. Document type definitions & $\mathbf{1}$ & $\mathbf{2}$ & $\mathbf{3}$ & $\mathbf{4}$ & $\mathbf{5}$ & 100 \\
\cline { 3 - 7 } & & $11.1 \%$ & & $33.3 \%$ & $22.2 \%$ & $33.3 \%$ & $\%$ \\
\hline & d. XML Scheme & $\mathbf{1}$ & $\mathbf{2}$ & $\mathbf{3}$ & $\mathbf{4}$ & $\mathbf{5}$ & 100 \\
\cline { 3 - 6 } & & & $22.2 \%$ & $44.4 \%$ & $22.2 \%$ & $\%$ \\
\hline
\end{tabular}


Determine the level of importance of entering the following topics in the accounting information system course or computer accounting course modules

$(1=$ not important, 5 = very important $)$

\begin{tabular}{|c|c|c|c|c|c|c|c|}
\hline \multirow[t]{2}{*}{15} & \multirow{2}{*}{ a. XML / XBRL } & 1 & 2 & 3 & 4 & 5 & \multirow[b]{2}{*}{$100 \%$} \\
\hline & & & & $22.2 \%$ & $44.4 \%$ & $33.3 \%$ & \\
\hline & \multirow[t]{2}{*}{ b. Advance excel Techniques } & 1 & 2 & 3 & 4 & 5 & \multirow[b]{2}{*}{$100 \%$} \\
\hline & & & & $22.2 \%$ & $55.6 \%$ & $22.2 \%$ & \\
\hline & \multirow[t]{2}{*}{ c. General ledger software } & 1 & 2 & 3 & 4 & 5 & \multirow[b]{2}{*}{$100 \%$} \\
\hline & & & & $33.3 \%$ & $33.3 \%$ & $33.3 \%$ & \\
\hline & \multirow[t]{2}{*}{ d. Data base software } & 1 & 2 & 3 & 4 & 5 & \multirow[b]{2}{*}{$100 \%$} \\
\hline & & & & $22.2 \%$ & $33.3 \%$ & $44.4 \%$ & \\
\hline & \multirow[t]{2}{*}{ e. Software flowcharting } & 1 & 2 & 3 & 4 & 5 & \multirow[b]{2}{*}{$100 \%$} \\
\hline & & & & $33.3 \%$ & $22.2 \%$ & $44.4 \%$ & \\
\hline & \multirow[t]{2}{*}{ f. Software working trial } & 1 & 2 & 3 & 4 & 5 & \multirow[b]{2}{*}{$100 \%$} \\
\hline & & & & $33.3 \%$ & $22.2 \%$ & $44.4 \%$ & \\
\hline
\end{tabular}

Determine the importance of the method for presenting XBRL by marking numbers $(1=$ not important, 5 = very important $)$

\begin{tabular}{|c|c|c|c|c|c|c|c|}
\hline \multirow[t]{2}{*}{16} & \multirow[t]{2}{*}{ a. TextBook } & 1 & 2 & 3 & 4 & 5 & \multirow[t]{2}{*}{$100 \%$} \\
\hline & & & & $22.2 \%$ & $44.4 \%$ & $33.3 \%$ & \\
\hline & \multirow[t]{2}{*}{ b. Tutorial } & 1 & 2 & 3 & 4 & 5 & \multirow[t]{2}{*}{$100 \%$} \\
\hline & & & & $22.2 \%$ & $22.2 \%$ & $55.6 \%$ & \\
\hline & \multirow[t]{2}{*}{ c. Video } & 1 & 2 & 3 & 4 & 5 & \multirow[t]{2}{*}{$100 \%$} \\
\hline & & & & $33.3 \%$ & $22.2 \%$ & $33.3 \%$ & \\
\hline & \multirow[t]{2}{*}{ d. Textbook Support } & 1 & 2 & 3 & 4 & 5 & \multirow[t]{2}{*}{$100 \%$} \\
\hline & & & & $22.2 \%$ & $3.33 \%$ & $44.4 \%$ & \\
\hline & \multirow[t]{2}{*}{ e. Case materials } & 1 & 2 & 3 & 4 & 5 & \multirow[t]{2}{*}{$100 \%$} \\
\hline & & & & $22.2 \%$ & $22.2 \%$ & $55.6 \%$ & \\
\hline
\end{tabular}

From table 3 it can be seen that the majority of respondents consider that the topic of XBRL covers in the accounting information system subject, $22.2 \%$ said it was important to be accommodated in the subject stand-alone accounting and others state that the topic of XBRL is included in the computer accounting class. From the description of respondents' answers, it is known that lecturers who have not presented XBRL into their curriculum, plan to include the XBRL topic into the accounting curriculum within this year. This shows a positive response to accounting lecturers for technological developments in the financial reporting system. This positive response also shows that the development of this technology is also considered important to be taught in accounting classes.

In table 3, point 10 questions a to $\mathrm{d}$ explain that respondents consider that XBRL material is considered very important for the accounting curriculum to provide enough topics related to XBRL. Some respondents also consider that XBRL should be included in accounting standards. So as many as $66.7 \%$ of respondents stated that the XBRL topic was needed. This shows the respondent's knowledge of XBRL's technology needs as well as its benefits. Respondents also feel that this XBRL technology must be introduced to accounting students. But around $44.4 \%$ of respondents also thought that the XBRL topic was not needed, this indicates that the adoption of the financial reporting system with XBRL technology has not been well socialized to academics and practitioners. Academics also consider that academics have not been so important to apply.

As many as $66.7 \%$ of respondents consider that XBRL has important potential in the future. But of course the integration of XBRL into the accounting curriculum also faces challenges, because as many as $66.7 \%$ of respondents that attempted to integrate this XBRL material had a slightly heavy obstacle as well. So that only $11.1 \%$ of respondents stated that there were no obstacles. In accordance with the results of Rahwani's research [2], the most common problem faced is the lack of books, references and articles about XBRL.

Of the 9 XBRL material lists, there are 5 topics that are considered important and very important to be accommodated, namely: Document type definitions (44.4\%), XML / XBRL Schemes (44.4\%), XBRL Components (55.6\%), XSL/XBRL Software $(44.4 \%)$ and XBRL strategic use $(44.4 \%)$ and the remaining 4 topics were considered important enough by some respondents to be accommodated. The answers of respondents of the accounting lecturers who considered the importance and importance of XBRL topics to be accommodated in the Accounting Information Systems course, Management Information System and Computer Accounting, showed that respondents 
agreed with the XBRL topic coverage in the course. The subject course must accommodate the XBRL topic because the application of XBRL technology in the financial reporting system in Indonesia, especially in the published banking financial reports on the Indonesian stock exchange has been applied even though it is still voluntary. Of course, this policy must be supported by accounting academics in preparing students to face the world of work.

Furthermore, the results and Discussion of Part Three on question 14 at point ad state the depth of coverage of each material from the XBRL topic. Some respondents stated that the material of Markup and Price Concepts $(44.4 \%)$ and Elements, attributes and namespace in XML / XBRL (66.7\%) at the deepening level were sufficient coverage. This is in accordance with the results of Rahwani's research [2] that for vocational and SI students that XBRL material is only at the introduction stage, it means that it is not deep or very deep. Only an introduction. But on the material the definitions of document types by respondents are considered to be very deep in scope by $33.3 \%$ of respondents while some other respondents consider only at a sufficiently deep level. In the XML / XBRL Scheme material, respondents assume that this material is important to be introduced in the classroom and in a deep level of coverage. This means that accounting lecturers consider that the XBRL Scheme must be understood by students.

Based on the 15th question on points ae is determining the level of importance of entering XBRL topics in the Accounting and Computer Accounting Information System subjects, it can be seen that most respondents consider XBRL material to be important $(44.4 \%)$ and $33.3 \%$ consider the material this is very important. Likewise, the matter of Advance excel techniques is also considered important $(55.6 \%)$. Whereas in general ledger software material in the same response by respondents as much as $33.3 \%$ stated quite important, important and very important. For database software materials and software flowcharting and software working trials (44.4\%) in response by respondents is very important. These results indicate that actually SIA lecturers and accounting computers have been able to determine which material is most considered important to teach in class. Most respondents already know XBRL and already know what material is needed in introducing XBRL material. This shows that the topic of XBRL is indeed considered beneficial for students. Making students more desirable in the job market is also a very important benefit because the goal of higher education is ultimately to produce graduates who can be absorbed by the labor market.

For the last question in the third part of the questionnaire is to determine the importance of the method of presenting XBRL in class. As many as
$44.4 \%$ of respondents stated that it was important for the method of presenting XBRL with the textbook and $33.3 \%$ of respondents considered it very important. While the other four questions assume that the teaching method with Tutorials, videos, the presence of supporting textbooks and case materials is considered very important in presenting the XBRL topic in the class. The results of the answers to the last question are very important as a basis for recommending how to present the XBRL topic to students. Because the XBRL topic is a new topic, it is certainly necessary to find the right way to teach the XBRL topic according to accounting academies, especially lecturers who teach SIA courses, SIM and computer accounting.

\section{CONCLUSION}

Based on the results and discussion described above, it can be concluded that according to academics are (1) it is very important to integrate XBRL material into AIS, MIS and Computer Accounting courses; (2) XBRL topics that are considered very important to be taught in class are: document type definitions, XBRL components, XSL / XBRL software, and XBRL strategic uses or the benefits of XBRL technology; (3) The level of coverage of each material that is considered to be presented in depth is on the definition of each document and XBRL scheme; (4) Respondents assume that the XBRL presentation method must be with a textbook, tutorial, video, textbook support and case materials.

\section{REFERENCES}

[1] A. Desmukh, XBRL In The Accounting Curriculum: a Survey Of AIS Faculty, 2006.

[2] N.R. Rahwani, How to Integrate XBRL into Accounting Curriculum at Banjarmasin State Polytechnic, Inf. Syst. Int. Conf. (2013) 2-4.

[3] B. Indonesia, Reporting System Integration Using the XBRL, Methodology. 2013.

[4] D. Hendratto, Study of Electronic Financial Statement Analysis, BAPEPAM, Jakarta, 2005.

[5] C. Wirabuana, Nugraha, Performance Analysis of XBRL Technology for Financial Statements in Financial Industry, University of Indonesia, 2014.

http://lib.ui.ac.id/detail?id=20388479\&lokasi= lokal.

[6] Y. Wada, XBRL in Asia and Oceania Region, NTT DATA Corp. 2013.

[7] M.I. Gomaa, A. Markelevich, L. Shaw, Introducing XBRL through a financial statement analysis project, J. Account. Educ. 29 , $153-173$.

2011 https://doi.org/10.1016/j.jaccedu.2011.12.001. 
[8] Bapepam, Benefits of XBRL. http://www.bapepam.go.id/old/xbrl/id. 2013.

[9] E.E. Cohen, T. Schiavina, O. Servais, XBRL: The standardised business language for $21 \mathrm{st}$ century reporting and governance, Int. J. Discl. Gov. $2 . \quad 368-394.2005$. https://doi.org/10.1057/palgrave.jdg.2040006.

[10] J. Fedorowicz, Integrating XBRL Into The Accounting Curriculum, Rev. Bus. Inf. Syst. 7 51-62.

2003. 